clinic are required to check the equipment. Could these strict conditions possibly influence bony union? Introductory statements to review articles such as "At this time the weight of evidence gathered from both laboratory, animal, and clinical studies indicates that electrical forces can stimulate bone growth. The prime question thus becomes, how does it work?" ${ }_{27}$ and "A double blind trial is impracticable" ${ }_{28}$ suggested that this question is not always addressed.

Fortunately, such statements did not deter Barker et al from randomly allocating 16 patients with ununited tibial fractures of at least 12 months' duration to treatment with either an active or dummy pulsed magnetic field stimulator contained within a full non-weight-bearing plaster..$^{29}$ The two groups were reviewed after 24 weeks. The fractures in five of the nine patients with an active stimulator united compared with five of the seven of those in the control group. Finding no difference between the two groups, the authors argued the efficacy of conservative treatment. This preliminary communication was the first reported double blind trial of pulsed magnetic field therapy for tibial non-union in man. We and 11000 patients world wide await the results of further double blind controlled trials.

Clinical Reader in Orthopaedic Surgery,

JOHN NIXON

Nuffield Orthopaedic Centre,

Oxford OX $37 \mathrm{LD}$

1 Stillings D. Healing fractures electrically. Fourmal of the Association for Advancement of Medicul Instrumentation 1974;8:259.

2 Bassett CAL, Pawluk RJ, Becker RO). Effects of electrical current on bone formation in vivo. Nature 1964;204:652-4.

3 Gross D, Williams WS. Streaming potential and the electromechanical response of physiologically moist bone. f Biomech 1982;15(4):277-95.

4 Borgens R. Fndogenous ionic currents transverse intact and damaged bone. Science 1984;225: 478-82.

5 Rubinacci A, Tessari L. A correlation analysis between bone formation rate and bioelectric potentials in rabbit tibia. Calct Tissue Int 1983;35:728-31.

6 Friedenburg ZB, Roberts PG, Didizian NH, Brighton CT. Stimulation of healing by "direct current" in the rabbit fibula. 7 Bone 7 oint Surg 1971;53A: 1400-8.

Hassler CR, Rybicki EF, Diegle RB, Clark LC. Studies of enhanced bone healing via electrica stimuli. Clin Orthop 1977;124:9-19.

8 Bassett CAL. Pulsing electromagnetic fields: a new method to modify cell behaviour in calcified and noncalcified tissues. Calcif Tissue Int 1982;34:1-8.

9 Fitton-Jackson S, Jones DB, Murray JC, Farndale RW. The response of connective and skeleta tissues to pulsed magnetic fields. In: Transactions of the first annual meeting, Bioelectrical Repair and Growth Society. Philadelphia: Bioelectrical Repair and Growth Society 1981:1-85.

10 Norton LA, Rodan GA, Bourrett LA. Epiphyseal cartilage CAMP changes produced by electrical and mechanical perturbations. Clin Orthop 1977;124:59-68

11 Fitton-Jackson S, Bassett CAL. The response of skeletal tissues to pulsed magnetic fields. In Richards RJ. Rajan KT, eds. Tissue culture in medical research (II). Oxford: Pergamon Press, 1980:21-8

12 Spadaro J. Electrically stimulated bone growth in animals and man. Clin Orthop 1977;122:325-32

13 Brighton CT, Black J, Friedenberg ZB, Estherhi JL, Day LJ, Connolly JF. A multicenter study of the treatment of non-union with constant direct current. F Bone foint Surg 1981;63A:2-13.

14 Heppenstall RB. Constant direct current treatment for established non-union of the tibia. Clin Orthop 1983;178:179-84

15 Bassett CAL, Mitchell SN, Gaston SR. Pulsing electromagnetic field treatments in ununited fractures and failed arthrodeses. $\mathcal{F}$ AMA 1 1982;247:623-8

16 Bassett CAI., Mitchell SN, Schink MM. Treatment of therapeutically resistant non-unions with bone grafts and pulsing electromagnetic fields. F Bone fout Surg 1982;64A:1214-20.

17 Connolly JF. Selection evaluation and indications for electrical stimulation of ununited fractures Clin Orthop 1981:161:39-53.

18 Watson $\mathrm{J}$. The electrical stimulation of bone healing in cases of non-union and delayed union. In McKibbin B, ed. Edinburgh: (Churchill Livingstone, 1983:131-53

19 Puranen J, Kaski P. The clinical significance of osteomedullography in fracture of the tibial shaft. f Bone Foint Surg 1974:56A:759.

20 Rhinelander F. Circulation of bone. In: Bourne $\mathrm{G}$, ed. The hochemistry and phystology of hone. Vol 11. New York: Academic Press, 1972:2-77.

21 Esterhai JL, Brighton CT, Heppenstall RB, Alavi A, Desai AG. Detection of synovial pseudarthroses by $99 \mathrm{~m}$ Ti scintigraphy. Clin Orthop 1981;161:15-23.

22 Muller ME, Thomas RJ. Treatment of non-union in fractures of long bones. Clin Orthop 1979:138:141-53.

23 Reckling WR, Waters $\mathrm{CH}$. Treatment of non-union of fractures of the tibial diaphysis by

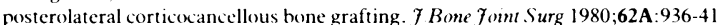

24 Boyd HB, Lipinski SW, Wiley JH. Observations on non-union of the shafts of long hones with statistical analysis of 842 patients. F Bone foint Surg 1961;43A:159-68.

25 Nicoll EA. Fractures of the tibial shaft-a survey of 705 cases. 7 Bone foint Surg 1964;46B: $373-87$

26 Watson-Jones $R$. Slow union of fractures with a studv of 804 fractures of the shafts of tibia and femur. Br 7 Surg 1943:30:260-76.

27 Becker RO. Electrical osteogenesis-- pro and con. Calcif Tissue Res 1978;26:93-7.

28 De Haas WG, Watson J, Morrison DM. Non-invasive treatment of ununited fractures of the tibia using electrical stimulation. F Bone foimt Surg 1980;62B:465-70.

29 Barker AT, Dixon RA, Sharrard WJW, Sutcliffe ML. Pulsed magnetic field therapy for tibia non-union: interim results of a double blind trial. Lancet 1984;i:994-6

\section{Antibiotics in hand infections}

Antibiotics have brought respite for many patients suffering with severe infections, but their indiscriminate use may be damaging. Nowhere is this more true than in the hand. The old aphorism that there is "no such thing as a minor hand infection" remains true. Furthermore, hand infections which might be thought to be minor by both patient and doctor may be transformed into major problems if antibiotics are prescribed unwisely. While dogma may be dangerous, as a general rule the outpatient prescription of antibiotics alone has no place in treating hand infections. Where antibiotics are indicated-and they often are-is as an adjuvant to surgical treatment; or when surgical treatment is not indicated antibiotics may be required parenterally, together with splintage and elevation of the arm in hospital. ${ }^{1-10}$

The common hand infections are paronychia (whitlow), pulp space infection (felon), boils, and cellulitis; together they account for $90 \%$ of the total. Acute paronychia occurs in three stages of severity. Firstly, there may be pus between the reflected cuticle and the nail; secondly, a small amount of pus may have formed under the lateral part of the nail; and, thirdly, the so called "horseshoe" paronychia may have developed, with pus insinuated between the proximal nail and the nail germinal matrix. All three forms are best treated surgically, followed by daily dressings and splintage. Antibiotics are seldom necessary. Pulp space infections require incision and drainage, daily dressings, and splintage of the digit, and again antibiotics are seldom necessary. Only when the infection is seen late and a "collar stud" type of abscess has developed, possibly with secondary spread to the bone, are adjuvant antibiotics appropriate. Boils on the hand and wrist occur almost exclusively on the dorsal aspect, in hair bearing skin, and require incision and drainage followed by splintage. If there is surrounding erythema or pronounced swelling the hand should be elevated and antistaphylococcal antibiotics given parenterally.

Cellulitis is almost always the result of infection with $\beta$ haemolytic streptococci, and treatment should consist of splintage of the hand in the safe position, elevation, and intravenous benzylpenicillin.

The less common but more serious infections are the abscesses that may form in the web space, the palmar space, or the thenar space. All these require incision and drainage under regional or general anaesthesia and a tourniquet. Antistaphylococcal antibiotics, given parenterally, should be given initially until organisms have been cultured and their sensitivities are obtained. Infection of the flexor tendon sheath requires incision, drainage, and irrigation of the tendon sheath, together with parenteral benzylpenicillin. Septic arthritis may occur after an injury initially thought to be trivial; it may also result from a punch in which the clenched fist strikes the incisor teeth. The required treatment is opening and irrigation of the joint and the administration of broad spectrum antibiotics to cover the wide range of organisms present in the mouth.

Pyogenic granulomas require curettage. Orf is a self limiting granulomatous condition, the result of inoculation of the skin with a virus that lives in the incisor teeth of sheep. Herpes simplex and, more recently, genital herpes may produce unusual patterns of infection around the nail. Tuberculosis may affect bones or joints, but in Britain the flexor tendon synovium is the commonest site of infection in the hand, producing the so called "compound palmar 
ganglion." Treatment consists of synovectomy and antituberculous chemotherapy. Acute non-suppurative arthritis occurs only rarely in the hand. Gout may go unsuspected for some time.

If antibiotics are administered inappropriately the course of the infection is frequently modified to the patient's detriment. Chronic infection may result, with swelling, induration, and stiffness of the digit or hand. This may be difficult to resolve and may, indeed, result in persistent functional disability. Changes in the articular cartilage of infected joints progress rapidly and move toward secondary osteoarthrosis. Adhesions in the flexor tendon apparatus may produce severe limitation of the excursion of the flexor tendons and require tenolysis.

The prescription of antibiotics as the sole treatment of a hand infection must therefore be undertaken with circumspection. The penalty for errors is great. The result of a hand infection, or a hand injury, is almost always related to the quality of the primary treatment. Primary treatment cannot be instituted correctly unless the diagnosis is also correct. When there is doubt, therefore, the patient should be referred to a hand surgeon immediately.

NeIL Watson

Consultant Hand Surgeon,

Milton Keynes Hospital,

Milton Keynes MK6 5LD

1 Bailey D. The infected hand. London: H K Lewis, 1963.

Carter PR. Common hand injuries and infections. A practical approach to early treatment. Philadelphia: W B Saunders, 1983.

3 Clarkson P, Pelly A. The general and plastic surgery of the hand. Oxford: Blackwell Scientific Publications, 1962

4 Flynn JE. Hand surgery. Baltimore: Williams and Wilkins, 1975.

5 Lamb DW, Kuczynski K. The practice of hand surgery. Oxford: Blackwell Scientific Publications, 1981

6 Lister G. The hand: diagnosis and indications. Edinburgh: Churchill Livingstone, 1977.

7 Milford L. The hand in Campbell's operative orthopaedics. St Louis: C V Mosby, 1981

8 Sneddon J. The care of hand infections. London: Edward Arnold, 1970.

9 Watson N. Hand injuries and infections. London: Gower (in press

10 Watson N. Practical management of musculoskeletal emergencies. Oxford: Blackwell Scientific Publications (in press).

\title{
New hepatitis B vaccines
}

\author{
ARIE J ZUCKERMAN
}

Viral hepatitis is a major public health problem in all parts of the world. The infection may be caused by any of half a dozen viruses: hepatitis $\mathrm{A}$, hepatitis $\mathrm{B}$, hepatitis $\mathrm{D}$ (the delta agent, a defective virus), epidemic non-A hepatitis, and by at least two non- $A$, non- $B$ viruses.

Hepatitis B (fig 1) affects every part of medical practice and its importance cannot be exaggerated. Infection may progress to chronic liver disease, including chronic persistent and chronic active hepatitis, cirrhosis, and hepatocellular carcinoma, one of the most common malignant tumours. Persistent infection is common, particularly if acquired early in life, and at a conservative estimate there are 200 million carriers of hepatitis B world wide.' Immunisation against hepatitis B is, therefore, required for groups at high risk of infection, as assessed by epidemiological patterns, socioeconomic factors, cultural and sexual practices, and the environment. ${ }^{2}$

The high rates of infection and perinatal transmission of hepatitis B in some regions dictate the urgency of protective immunisation of susceptible women of childbearing age and of infants-and particularly of infants born to carrier mothers-as the only practical way of interrupting transmission of the infection. ${ }^{3}$ Immunisation must also be considered for people living in certain tropical and non-tropical areas where the prevalence of hepatitis B infection is high, where $10-20 \%$ or more of the population may be carriers, and where primary liver cancer is common.

The development, safety, and efficacy of hepatitis B vaccine consisting of the excess surface antigen protein coat of the virus purified from the plasma of asymptomatic carriers (fig 2) have been reviewed recently. ${ }^{2}$ This article describes the rapid advances which are being made with polypeptide vaccines, hepatitis $B$ vaccines produced by recombinant DNA technology, recombinant live hepatitis B vaccines, and chemically synthesised vaccines.

\section{Hepatitis B polypeptide vaccines}

There are two main polypeptides of purified hepatitis B surface antigen, one with a molecular weight of 22000 to 25000 or 26000 (variations exist among the results of analyses of purified antigen from different sources) and the other, its glycosylated form, with a molecular weight of 28000-30000. These have been designated p25 and gp30. The polypeptide vaccines contain both p25 and gp 30 and have been prepared and tested for safety, immunogenicity, and protective efficacy in susceptible chimpanzees. ${ }^{45}$ When compared with the plasma vaccine these polypeptide vaccines are better defined chemically and have an added margin of 